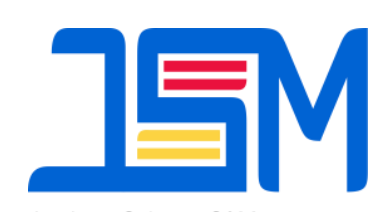

\title{
JAMBURA SCIENCE OF MANAGEMENT
}

Homepage : http://ejurnal.ung.ac.id/index.php/jsm

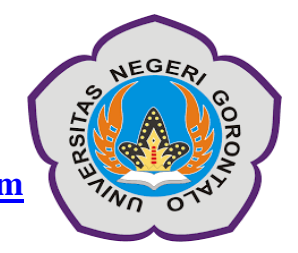

\section{The Effect Of Human Relation And Environmental Conditions On Employees Work Ethic}

\author{
Suryadin Suryadin ${ }^{1}$, Mistar Mistar ${ }^{2}$ \\ ${ }^{1,2}$ Human Resource Management Study Program, Sekolah Tinggi Ilmu Ekonomi Bima, Nusa \\ Tenggara Barat, Indonesia \\ Monginsidi Street, Bima City, Telp. (0374)42556 \\ E-mail: ${ }^{1}$ johnyedon@gmail.com; ${ }^{2}$ mistar.stiebima@gmail.com
}

\begin{abstract}
:
The purpose of this study was to determine and analyze the effect of human relations and working environment conditions partially and simultaneously on the work ethics of Woha's Procurement Service Unit employees. The research method used is associative with a quantitative approach. The sampling technique used was saturated sampling so that the entire population was used as a sample in this study as many as 53 respondents, the research instrument was a questionnaire or questionnaire. Data analysis techniques used are the validity and reliability test, the classic assumption test, multiple linear regression analysis, the coefficient of detemination, the $\mathrm{t}$ test and the $\mathrm{F}$ test. Based on the results of statistical tests conducted partially human relations have a positive and significant effect on the work ethic of Woha's Procurement Service Unit employees. Based on the results of statistical tests conducted partially human relations have a positive and significant effect on the work ethic of Woha's Procurement Service Unit employees. While the work environment conditions have a negative and not significant effect on the work ethics of Woha's Procurement Service Unit employees. Simultaneously, human relations variables and work environment conditions significantly influence the work ethics of Woha's Procurement Service Unit employees.
\end{abstract}

\section{Keywords: Human Relations; Working Environment Conditions; Work ethic}

Human Resources is a major factor for every organization, therefore organizations need to pay serious attention to the existence of these Human Resources. There are several factors that can affect organizational performance in totality, among others; Human relations, working environment conditions, compensation, discipline, loyalty, work ethic and so on. Organizations must create human retion wherever possible. Avoid disputes and disputes between employees, each problem must be resolved as soon as possible. The other most important thing in creating a 
work ethic is the work environment. The work environment is the conditions that occur and are around the workplace such as facilities and work targets. Included in the work facilities and infrastructure, namely the room, table-chairs, noise, environmental cleanliness, and various other arrangements. Things like this will be able to create a work ethic.

Based on previous research, as conducted by Achmad Wahyu Eriyanto, Hadi Sunaryo, M. Khoirul ABS (2015) with the title Influence of Human Relations, Working Environment Conditions and Leadership Style on Work Ethics (Case Study on Administrators of Ilham Ramadhan Student Cooperatives, Islamic University of Malang). The analysis shows that partially and jointly shows that human relations, working environment conditions, and leadership style significantly influence the work ethic. Furthermore, a study by Sepris Yonaldi, Henny Sjafitri, Bustami in 2018 with the title Analysis of the Effect of Human Relations and Working Environment Conditions on the Work Ethics of Pharmacy Installation Employees. Dr. M. Djamil Padang. Based on the results of tests conducted partially and simultaneously variables of human relations and working environment conditions significantly influence the work ethic of the Pharmacy Installation employee.

Human relations (Human Relations) is a harmonious human relationship, created by the awareness and willingness to fuse individual desires for the integration of common interests, the aim is to produce sufficiently strong integration, encourage productive and creative cooperation to achieve common goals Hasibuan (2013).
Susanti (2014) Human relations is the relationship or interaction and communication between one employee and other employees, both in work situations or outside the work environment. Human relations are human relationships that are always needed by employees, where their function is as personal beings and social beings, the need for other people to work together in achieving their life goals. A harmonious relationship will create a pleasant working atmosphere and this will affect the enthusiasm of employees in carrying out all their work (Saputro, 2017)

\section{The influence of human relations on work} ethic

Employee human relations are human relationships that are always needed by employees, where the function is as a personal being and social beings, the need for other people to work together in achieving their life goals. A harmonious relationship will create a pleasant work atmosphere and this will affect the enthusiasm of employees in carrying out all their work (Saputro, 2017). According to Susanti's research (2014) human relations are humane interpersonal communication, which means that communication has entered a psychological stage where the communicator and the communication understand each other's thoughts, feelings and take actions together so that it can affect the work ethic for each employee

\section{Effect of working environment conditions on work ethic}

The condition of the work environment is a position and circumstances in which the employee works. The work environment for employees will have a significant influence on the running of a 
company's operations. The work environment will be able to influence the work ethic of employees directly or indirectly (Budianto, 2015). A good and satisfying working environment will certainly improve employee work ethic

The Influence of Human Relations and Working Environment Conditions on Employee Work Ethics

The condition of the work environment is the overall relationship that occurs with employees at work. Everything in the workplace is a work environment. Employees are in a work environment when employees do work activities, and all forms of relationships involving these employees, including from the work environment. Relations between humans and physical environment conditions affect the work ethic of employees, if the work ethic of employees in a company decreases, automatically the performance of employees will also decrease.

Based on a review of theory and previous research, a conceptual framework of research can be proposed as follows:

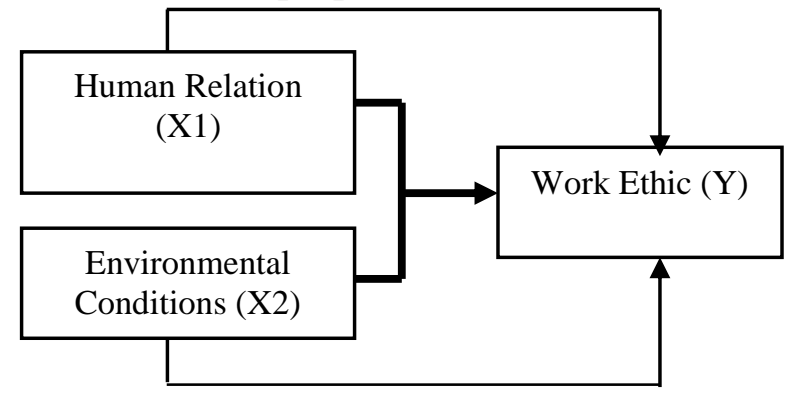

Figure 1. Research Design

H1: Human relations affects the work ethic of Woha Procurement Service Unit (ULP) staff in Bima Regency

$\mathrm{H} 2$ : Working environment conditions affect the work ethic of Woha Procurement
Service Unit (ULP) staff in Bima Regency

H3: Human relations and environmental conditions jointly influence the work ethic of Woha Procurement Service Unit (ULP) staff in Bima Regency.

\section{METHOD}

This research is a quantitative research that is research in the form of numbers and analysis using statistics Quantitative research aims to show the relationship between variables, test theories, and look for generalizations that have predictive value. While this type of research is categorized as causal research Causal research is research that seeks to create a causal relationship. According to Husein (2013) causal design is used to measure the strength of relationships and influences between variables (X1), namely Human Relations, (X2) Working Environment Conditions on the dependent variable (Y) Employee work ethic. The population in this study were all Bima ULP employees, totaling 53 employees. The sample in this study were ULP Bima employees, totaling 53 people. The sampling technique used in this study is total sampling (Darmawan, 2014). The reason for using total sampling in this study is because the population is considered small. The type of data used in this study is primary data obtained directly from Woha ULP employees in Bima Regency. Where the data collection technique is by conducting interviews with several respondents and giving questionnaires to Woha ULP employees who have been determined as samples in this study, interval measurement scale with a 
Likert Scale model. This scale usually uses scale 1-5 which has a tip value that states strongly agree and strongly disagree. Data analysis test tool in this study uses a validity and reliability test, a classic assumption test, multiple linear regression analysis, correlation coefficient, coefficient of determination, F test and t-test. Statistical analysis can be done using the Multivariate Analysis Application with the IBM SPSS Program (Ghozali, 2013.

\section{RESULT}

\section{Validity and Reliability Test}

The results of the validity test of each statement submitted in the questionnaire to respondents showed that all items of the statement in the questionnaire were declared valid because the value of $r$ product moment $>\mathrm{r}$ table at a significance level of $5 \%$, then all items were variable questions human relations, working environment conditions and work ethics of employees is declared valid. This means, there is no data that is invalid / missing. Thus the entire number of indicators can be used in this study. Testing the reliability of human relations variables, working environment conditions, and employee work ethics obtained a Cronbach Alpha value> 0.6. The reliability test results for all variables are reliable or feasible to be used as a measurement tool in this study. Thus the data obtained in this study are suitable for use in the following analysis.

\section{Normality test}

To find out the data used are normally distributed or cannot use the Kolmogorov-Smirnov test. If the significance or probability value $>$ of $\alpha=$ 0.05 ", then the data is normally distributed.

Table 1. Kolmogrov Smirnov

One-Sample Kolmogorov-Smirnov Test

\begin{tabular}{llrrr}
\hline & & $\mathrm{X} 1$ & $\mathrm{X} 2$ & $\mathrm{Y}$ \\
\hline $\mathrm{N}$ & & 53 & 53 & 53 \\
Normal & Mean & 33.4906 & 30.7547 & 34.0000 \\
Parameters $^{\mathrm{a}}$ & Std. Deviation & 3.40035 & 4.32749 & 4.59933 \\
Most Extreme & Absolute & .126 & .104 & .145 \\
Differences & Positive & .055 & .104 & .133 \\
& Negative & -.126 & -.080 & -.145 \\
Kolmogorov-Smirnov Z & .914 & .755 & 1.052 \\
Asymp. Sig. (2-tailed) & .373 & .618 & .218 \\
\hline a. Test distribution is Normal. & & &
\end{tabular}

Source: Primary data processed, 2020

The results of the normality test with the Kolmogorov Smirnov test can be known the value of each variable that is 0.373 (X1),
0.618 (X2) and 0.218 (Y). From these results sig values> 0.05. So it can be concluded that the research data is normally 
distributed, meaning that the variables in the study have a normal distribution.

\section{Multicollinearity Test}

To detect the presence or absence of multicollinearity can be seen in the value of tolerance and VIF. If the tolerance value is above 0.1 and the VIF value is below 10 then there is no multicollinearity. The results of the multicollinearity test for the regression model in this study are presented in the table below:

Table 2. Multicollinearity Test Results

\begin{tabular}{lrr}
\hline & \multicolumn{2}{c}{ Collinearity Statistics } \\
Model & Tolerance & VIF \\
\hline (Constant) & & \\
X1 & .999 & 1.001 \\
X2 & .999 & 1.001 \\
\hline
\end{tabular}

a. Dependent Variable: $\mathrm{Y}$

Source: Primary data processed, 2020

From the table above it can be seen that all variables have tolerance values above 0.1 and VIF values below 10, so it can be concluded that the regression model in this study did not occur multicollinearity, this shows that the independent variables namely human relations and environmental conditions work does not correlate with each other.

\section{Heteroscedasticity Test}

To test whether there is a heterokedasticity problem can be done by seeing whether there are certain patterns in the scatterplot graph between SRESID and ZPRED where the $\mathrm{Y}$ axis is residual and the $\mathrm{X}$ axis is predicted.

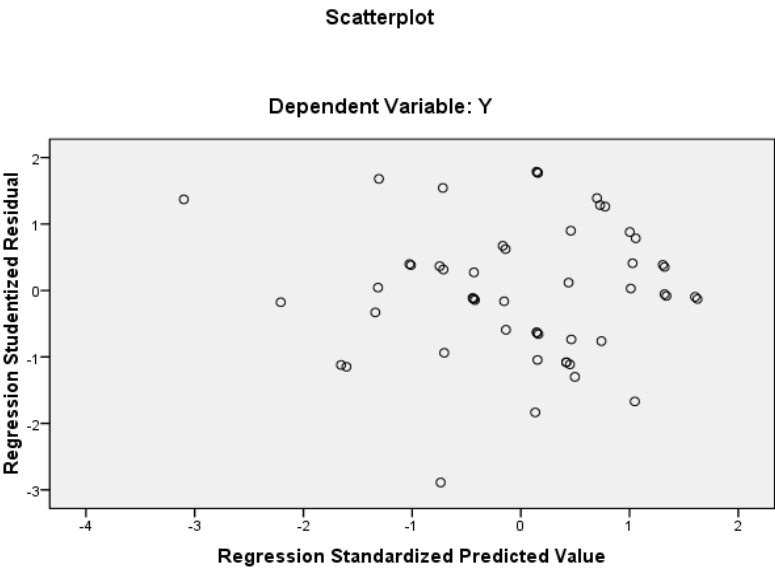

The scatterplot figure above snows that Heteroscedasticity does not occur pattern and tnese points spread above and because the points do not form a certain 
regression model is feasible to be used to predict the $\mathrm{Y}$ variable.

Multiple Linear Regression
Following are the results of the multiple regression analysis conducted using the SPSS 22.00 for Windows program.

Tabel 3. Multiple Linear Regression

\begin{tabular}{|c|c|c|c|c|c|c|}
\hline \multirow[b]{2}{*}{ Model } & \multicolumn{2}{|c|}{ Unstandardized Coefficients } & \multirow{2}{*}{\multicolumn{2}{|c|}{$\frac{\text { Standardized Coefficients }}{\text { Beta }}$}} & \multirow[b]{2}{*}{$\mathrm{t}$} & \multirow[b]{2}{*}{ Sig. } \\
\hline & $\mathrm{B}$ & Std. Error & & & & \\
\hline 1 (Constant) & -3.792 & 4.180 & & & -.907 & .369 \\
\hline $\mathrm{X} 1$ & 1.143 & .102 & & .845 & 11.168 & .000 \\
\hline $\mathrm{X} 2$ & -.016 & .080 & & -.015 & -.201 & .842 \\
\hline
\end{tabular}

a. Dependent Variable: Y

\section{Source: Primary data processed, 2020}

Based on the data analysis in the above table, the regression equation results are obtained as follows: $\mathrm{Y}=-3,792+$ 1,143X1 - 0,016X2

The influence of each human relations variable and working environment conditions on the work ethics of Woha's Procurement Service Unit (ULP) employees are as follows:

1. A constant of - 3,792 (negative) means that if the Human Relations variable and work environment conditions are negative, the employee work ethic is considered to decrease.

2. Human Relations variable regression coefficient of 1,143 (positive) means that if there is an increase in Human Relations while other factors are considered constant it will increase the employee work ethic.

3. The regression coefficient of the variable work environment condition is -0.016 (negative) meaning that if the work environment condition is negative or decreases while other factors are considered constant it will reduce the employee work ethic.

\section{Determinant Coefficient (R2)}

The coefficient of determination (R2) is used to find out how much the contribution of the independent variable to the dependent variable. In the use of the coefficient of determination expressed in percent so that it must be multiplied by $100 \%$, assuming $0 \leq \mathrm{r} 2 \geq 1$. Based on the test of the coefficient of determination can be seen in Table 4 as follows:

Table 4. Determinant Coefficient

Model Summary ${ }^{b}$

\begin{tabular}{lrrrrr}
\hline & & \multicolumn{4}{c}{ Adjusted R Std. Error of the } \\
Model & R & R Square & Square & Estimate & Durbin-Watson \\
\hline 1 & $.845^{\text {a }}$ & .714 & .702 & 2.50903 & 2.203 \\
\hline
\end{tabular}


Model Summary ${ }^{b}$

\begin{tabular}{lrrrrr}
\hline & & \multicolumn{4}{c}{ Adjusted R Std. Error of the } \\
Model & $\mathrm{R}$ & $\mathrm{R}$ Square & Square & Estimate & Durbin-Watson \\
\hline 1 & $.845^{\mathrm{a}}$ & .714 & .702 & 2.50903 & 2.203 \\
\hline
\end{tabular}

a. Predictors: (Constant), X2, X1

b. Dependent Variable: Y

Source: Primary data processed, 2020

The multiple correlation coefficient (R) of 0.845 means that the relationship between all independent variables, namely the human relations variable (X1), work environment conditions (X2) to the dependent variable, namely the employee work ethic (Y) is very strong. The coefficient of determination contained in the Adjusted R-Square value of 0.714 . This means that the contribution of the human relations variable (X1) and work environment conditions (X2) explains the work ethic variable by $71.4 \%$ while the remaining $28.6 \%$ is explained by other variables not used in this study such as the absence of job satisfaction, rewards (compensation) and pressure from superiors. $T$ test (Partial Test)

T-test was used to determine the effect of each independent variable on the statistically significant dependent variable. Based on the partial $t$ test can be seen in the following table;

Table 5. T Test Result

\begin{tabular}{|c|c|c|c|c|c|c|}
\hline \multirow[b]{2}{*}{ Model } & \multicolumn{2}{|c|}{ Unstandardized Coefficients } & \multicolumn{2}{|c|}{ Standardized Coefficients } & \multirow[b]{2}{*}{$\mathrm{t}$} & \multirow[b]{2}{*}{ Sig. } \\
\hline & $\mathrm{B}$ & Std. Error & Beta & & & \\
\hline 1 (Constant) & -3.792 & 4.180 & & & -.907 & 369 \\
\hline $\mathrm{X} 1$ & 1.143 & .102 & & .845 & 11.168 & .000 \\
\hline X2 & -.016 & .080 & & -.015 & -.201 & .842 \\
\hline
\end{tabular}

a. Dependent Variable: $\mathrm{Y}$

\section{Source: Primary data processed, 2020}

The human relations variable (X1) has a positive and significant effect on the work ethics of Woha's Procurement Service Unit (ULP) employees with a significant value of $0,000<0.05$. This can also be seen from the value of $\mathrm{t}$-count $>\mathrm{t}$-table with $\mathrm{df}=$ $\mathrm{n}-\mathrm{k}=53-3=50(2,008)$, so the value of $\mathrm{t}-$ count> t-table $(11,168>2,008)$ then the hypothesis H1 is accepted and Ho rejected.
Work environment condition variable (X2) does not have a positive and significant effect on Woha's Procurement Service Unit (ULP) employee work ethic with a significant value of $0.842>0.05$. This can also be seen from the value of $\mathrm{t}$-count $<\mathrm{t}$ table, so the value of $\mathrm{t}$-count $<\mathrm{t}$-table $(-0.201$ $<2.008)$ then the hypothesis $\mathrm{H} 2$ is rejected and Ho is accepted. 
F test (Simultaneous Test)

The F statistical test shows whether

all independent variables have a simultaneous influence on the dependent variable. The results of the simultaneous Ftest are as follows;

Table 6. F test

ANOVA ${ }^{b}$

\begin{tabular}{lrrrrr}
\hline Model & Sum of Squares & df & Mean Square & F & Sig. \\
\hline 1 Regression & 785.240 & 2 & 392.620 & 62.368 & $.000^{\mathrm{a}}$ \\
Residual & 314.760 & 50 & 6.295 & & \\
$\quad$ Total & 1100.000 & 52 & & & \\
\hline
\end{tabular}

a. Predictors: (Constant), X2, X1

b. Dependent

Variable: Y

\section{Source: Primary data processed, 2020}

From the SPSS test results obtained F-count between Human Relations $\left(\mathrm{X}_{1}\right)$, Work Environment $\left(\mathrm{X}_{2}\right)$, Employee Work Ethic (Y) of 62.368 and probability value of $0.000>0.05$. This means that the variable Human Relations $\left(\mathrm{X}_{1}\right)$, Work Environment Conditions $\left(\mathrm{X}_{2}\right)$, simultaneously (together) significantly influence the work ethic of Woha's ULP employee in Bima. Then the hypothesis test $\mathrm{Ho}$ is rejected and $\mathrm{H} 3$ is accepted.

\section{DISCUSSION}

\section{Effects of Human Relations on Employee Work Ethics}

This study seeks to test Human Relations on Employee Work Ethics based on the results of testing the Human Relations hypothesis positively and significantly affect Employee Work Ethics with a calculated t-coefficient of 11.168 and a significance value of 0.000 . This is due to the respondents who fill out the questionnaire are more likely to choose to agree (on a Likert scale shows a value of 4) if Human Relations will affect the Work Ethic. Where this indicates that Human Relations will not improve the Work Ethic, so the first hypothesis is accepted and supports research conducted by Sepris Yonaldi, Henny Sjafitri, Bustami (2018).

These results indicate that human relations is one of the factors that can influence the work ethic. This is because every employee has a sense of need for cooperation with other employees. Human relations in this case the need for cooperation is one of the essence of management, especially those related to humans, in the sense that the need for cooperation is the ability of a person to have a good relationship between people without being accompanied by differences between them. This will be able to create a unique outlook on life in a work group, where this view of life is actually a form of work ethic. With the need for cooperation among ULP Woha employees, a unique outlook on life 
will be created among them, with this unique outlook on life that will be able to bring up or improve the work ethic for employees.

\section{Effect of Environmental Conditions on} Employee Work Ethics

This study seeks to examine the Working Environment Conditions on Employee Work Ethics. Based on the results of hypothesis testing, the working environment condition does not have a positive and significant effect on the work ethics of Woha's Procurement Service Unit (ULP) employees. This is due to the respondents where they fill out the questionnaire are more likely to choose disagree (in the Likert scale shows a value of 3) if the Working Environment Conditions will not affect the Work Ethic. Where this indicates that the Working Environment Conditions will not increase the Work Ethic, so the second hypothesis is rejected and does not support research conducted by Sepris Yonaldi, Henny Sjafitri, Bustami (2018).

These results indicate that the condition of the work environment is not one of the factors that influence the work ethic. This is because ULP Woha employees are less capable in applying a physical and non-specific environmental conditions that are comfortable for work, where they accept to work with conditions that have been provided by the company, one of which is the coloring conditions in the workspace. With this it can be seen that in the company the employees do not bring up the totality of personality to express, look, believe and give meaning to something that encourages individuals to act and achieve optimal results (high performance) or can not bring up the work ethic in their personal - each employee (Tasmara, 2010). By accepting the environmental conditions that have been provided by the company, especially coloring in the workspace, inadequate work facilities as well as providing compensation to employees and security in the workplace which is felt to be lacking, they are less able to express and provide an optimal work result, this is what causing work ethic can not be realized.

\section{Effect of Human Relations and Environmental Conditions on Employee Work Ethics}

Human relations variables and working environment conditions together have a positive and significant influence on the work ethics of Woha's Procurement Service Unit (ULP) employees. The acceptance of the $\mathrm{H} 3$ hypothesis is influenced by employees who have the goal to empower themselves to achieve maximum work results and try to work independently, make adjustments at work so that each given job can be completed properly, can adjust to the ever-changing environment, so that with the work ethic it can make a good contribution to the Woha Procurement Service Unit (ULP) in achieving company goals.

The existence of human relations (relations between humans) that exist between employees with fellow employees and between employees and leaders with the support of work environment conditions both physical and environmental conditions that are good and comfortable non-physical environment will be able to improve employee work ethic. In accordance with the opinion of Manullang (2012) which states that a good work environment can not only 
increase employee productivity but also can improve employee work efficiency.

\section{CONCLUSION}

Based on the results of research that has been done, the following conclusions can be drawn: (1) Human relations have a significant effect on the work ethics of Woha Procurement Service Units (ULP) employees, this illustrates that creating good human relations will improve employee work ethics. By understanding the duties of each employee, they will be able to optimally create and improve their work ethic. (2) The condition of the work environment does not have a positive and significant effect on the work ethics of Woha's Procurement Service Unit (ULP) employees. Thus the existence of a good work environment in the company becomes very important in improving employee work ethic. (3) Simultaneously there is a positive and significant influence between human relations variables and working environment conditions on the work ethics of Woha Procurement Service Units (ULP) employees, this illustrates that creating good working relationships and harmonious working environment conditions will improve employee morale and work ethic.

\section{SUGGESTION}

Based on the conclusions stated above, suggestions can be made as follows: (1) From the results of this study human relations have been well established but need to be improved. With an increase in better human relations, it can be a basic motive for an employee to work better. (2)
For the condition of the work environment needs to be improved because in this study it has a negative effect on the work ethic, namely by providing adequate work facilities, job guarantees and compensation for the achievement of employee work outcomes which can ultimately affect the employee work ethic.

\section{ACKNOWLEDGMENT}

Our gratitude goes to the leaders of the Bima College of Economics (STIE), especially the chair of the BIE STIE management study program and the supervisor who provided the opportunity to conduct this research. we hope the results of this research can be useful for the academic world in particular.

\section{REFERENCES}

A. Anwar Prabu Mangkunegara, 2011, Manajemen Sumber Daya Manusia Perusahaan, PT. Remaja Rosdakarya, Bandung

Achmad Wahyu Eriyanto, dkk, Pengaruh Human Relation, Kondisi Lingkungan Kerja Dan Gaya Kepemimpinan Terhadap Etos Kerja (Studi Kasus pada Pengurus Koperasi Mahasiswa Ilham Ramadhan Universitas Islam Malang, e-Jurnal Riset Manajemen Fakultas Ekonomi Unisma.

Budianto, A. Aji, Tri., \& K, Amelia. 2015. Pengaruh Lingkungan Kerja Terhadap Kinerja Karyawan Pada PT. Perusahaan Gas Negara (PERSERO) Tbk SBU Distribusi Wilayah 1 Jakarta. Jurnal Ilmiah. Vol.3, No.1. 
Darmawan, D. 2014. Metode Penelitian Kuantitatif . Bandung: PT. Remaja Rosdakarya

Ghozali, I. 2013. Aplikasi Analisis Multivariate Dengan Program IBM SPSS 21 Update PLS Regresi (Edisi 7). Semarang : Badan Penerbit Universitas Diponegoro

Hadiansyah, A, \& Y, R, Purnamasari. 2015. Pengaruh Etos Kerja Terhadap Kinerja Karyawan PT. AE. Jurnal AlAzhar Indonesia Seri Humaniora. Vol.3, No.2

Hasibuan SP. Malayu. 2013. Manajemen Sumber Daya Manusia. Jakarta: PT. Bumi Aksara

Husein, Umar, 2015, Metode Riset Bisnis, Jakarta : Gramedia Pustaka Utama.

Josephine, A., \& H, Dhyah. 2017. Pengaruh Lingkungan Kerja Terhadap Kinerja Karyawan Pada Bagian Produksi Melalui Motivasi Kerja Sebagai Variabel Intervening Pada PT. Trio Corporate Plastic (Tricopla). Jurnal AGORA. Vol.5, No.3.

Istijanto. 2012. Riset Sumber Daya Manusia. Jakarta: PT. Gramedia Pustaka

Lubis, Aswadi. 2015. Lingkungan Kerja yang Kondusif dan Faktor-faktor yang Mempengaruhinya. Vol.3, No.1.

M. Manullang, 2012. Dasar-dasar Manajemen Bagi Pimpinan Perusahaan. Jakarta. Gajah Mada Press

Nuryasin, dkk, 2016. Pengaruh Lingkungan Kerja dan Motivasi Kerja Terhadap Kinerja Karyawan. Jurnal Administrasi Bisnis. Vol.41, No.1.

Rahmawanti, et.,al. 2014. Pengaruh Lingkungan Kerja Terhadap Kinerja
Karyawan. Jurnal Administrasi Bisnis. Vol.8, No.2.

Ramli, D \& M, Yunus. 2013. Pengaruh Iklim Organisasi, Etos Kerja dan Disiplin Terhadap Kinerja Karyawan Serta Dampaknya Terhadap Kinerja PT. Arun NGL Lhokseumawe Aceh. Jurnal Manajemen Pascasarjana Universitas Syiah Kuala Vol 2 ,No.1, 98-107

Samosir, Remalia. 2016. Pengaruh Kemampuan Intelektual dan Etos Kerja Terhadap Kinerja Karyawan Pada Kantor Pelayanan Kekayaan Negara dan Lelang Pematang siantar. Jurnal SULTANIST. Vol. 5, No.2.

Saputro, G, Adi., \& F, Azis, 2017. Analisis Pengaruh (Human Relation / Hubungan Antar Manusia) dan Kondisi Fisik Lingkungan Kerja Terhadap Etos Kerja dan Kinerja Karyawan PT. Karunia Adijaya Mandiri Semarang. Jurnal Administrasi Bisnis Vol 12. No. 06

Sedarmayanti. 2011. Sumber Daya Manusia dan Produktivitas Kerja. Bandung : CV Mandar Maju

Sepris Yonaldi, dkk, 2018. Analisis Pengaruh Human Relation Dan Kondisi Lingkungan Kerja Terhadap Etos Kerja Pegawai Instalasi Farmasi RSU. Dr. M. Djamil Padang. Menara Ekonomi, ISSN : 2407-8565; E-ISSN: 2579-5295 Volume IV No. 3 Oktober 2018

Sekaran, Umar. 2014, Metodologi Penelitian Untuk Bisnis. Edisi 4. Jakarta : Penerbit: Salemba Empat.. 
JSM, Volume 3, Number 1, January 2021

P-ISSN : 2655-3651

E-ISSN : 2656-0435

Sinamo, Jansen. 2012. Delapan Etos Kerja Profesional. Jakarta: PT. Spirit Mahardika.

Sugiyono. 2012. Statistika Untuk Penelitian. Bandung: Alfabeta.

Susanti, E, Cahyani Putri. 2014. Pengaruh Human Relation (Hubungan Antar Manusiadan Kondisi Lingkungan
Kerja Terhadap Kinerja Karyawan (Studi Pada Karyawan Dinas Pekerjaan Umum Cipta Karya Kabupaten Lamongan). Jurnal Administrasi Bisnis Vol. 17 No. 2.

Toto Tasmara. 2012. Etos Kerja Islami. Jakarta: Gema Insani Pres. 